\title{
David Oliver: Progress on dementia in hospital
}

\author{
David Oliver, consultant in geriatrics and acute general medicine
}

Berkshire

England's health secretary, Jeremy Hunt, used a speech in March to rehash the long running prime minister's challenge to raise standards of care for people with dementia. All Hunt really said about acute hospitals was that patients with "high dependency" would get consultant ward rounds twice a day and that some may have dementia - part of his "seven day services" crusade. ${ }^{1}$ This was a missed opportunity to celebrate good, progressive government initiatives and to rise above party politics.

The national dementia strategy was started by the Labour government in $2009,{ }^{2}$ but the 2010 coalition continued the programme, ${ }^{3}$ reinforced by the prime minister's challenge. ${ }^{4}$ This strategy made the care of hospital inpatients with dementia a priority. Calls for action from the Royal College of Physicians and the King's Fund noted that the care of inpatients with dementia was now everyone's business. ${ }^{56}$ We can't solve the problem by wishing patients away, and some patients really need to be in hospital for other reasons-however much we invest in services closer to home.

As many as $40 \%$ of hospital patients over 75 have dementia. It travels with them, although they're generally admitted for other primary reasons. They're more likely to die in hospital and to experience decompensation, depersonalisation, and harms. $^{8}$

Two reports, from the NHS Confederation and the Alzheimer's Society, ${ }^{9}{ }^{10}$ found that people with dementia occupy about a quarter of beds in acute hospitals. They stay about a week longer on average. Nurses feel untrained, unskilled, and less confident in assessing or treating them. Carers are often unhappy with the care and communication available.

Since 2010, more than 50 organisations have joined an umbrella group, the Dementia Action Alliance. ${ }^{11}$ The Royal College of Nursing has developed and shared good practice models. ${ }^{12}$ John's Campaign encourages many hospital wards to welcome and involve carers with open visiting. ${ }^{13}$

We're seeing growth in liaison psychiatry models within acute hospitals, in training the whole hospital workforce in dementia skills, and in hospitals employing their own dementia nurse practitioners. Many have created "dementia-friendly" ward environments using evidence based design. ${ }^{14}$ Others have employed activities coordinators. The Care Quality Commission has made dementia a key theme in its inspections.

Of course, these inputs are no use without tangible gains for patients and families, but we are seeing some. The Royal College of Psychiatrists' national audit has described dementia care in several domains, standards, and systems for 8000 patients in 210 hospitals. ${ }^{15}$ Sure, the audit shows variation and care gaps, but it's nonetheless an improving picture, unrecognisable from a decade ago.

We soon forget how far we've come and the importance of celebrating success, no matter who helped to start or tend the fire.

Competing interests: See www.bmj.com/about-bmj/freelancecontributors/david-oliver.

Provenance and peer review: Commissioned; not externally peer reviewed.

Oliver D. Government's rehashed dementia plans sum up why Jeremy Hunt has lost clinicians' trust. Guardian Healthcare Network 2016 Mar 16. www.theguardian.com/ healthcare-network/2016/mar/16/jeremy-hunt-dementia-nhs-contracts.

2 Department of Health. Living well with dementia: a national dementia strategy. 3 Feb 2009. www.gov.uk/government/uploads/system/uploads/attachment_data/file/168220/ dh_094051.pdf.

3 Department of Health. Quality outcomes for people with dementia: building on the work of the national dementia strategy. 28 Sep 2010. www.gov.uk/government/publications/ quality-outcomes-for-people-with-dementia-building-on-the-work-of-the-national-dementiastrategy.

4 Department of Health. Prime minister's challenge on dementia. 26 Mar 2012. www.gov. uk/government/uploads/system/uploads/attachment_data/file/215101/dh_133176.pdf.

5 Royal College of Physicians. Hospitals on the edge: the time for action. Sep 2012. www. rcplondon.ac.uk/guidelines-policy/hospitals-edge-time-action.

6 King's Fund. The care of frail older people with complex needs: time for a revolution. Mar 2012. www.kingsfund.org.uk/sites/files/kf/field/field_publication_file/the-care-of-frail-olderpeople-with-complex-needs-mar-2012.pdf.

7 Sampson EL, Blanchard MR, Jones L, Tookman A, King M. Dementia in the acute hospital: prospective cohort study of prevalence and mortality. Br J Psychiatry 2009;195:61-6. doi: 10.1192/bjp.bp. 108.055335 pmid:19567898.

8 Royal College of Psychiatrists. Who cares wins: improving the outcome for older people admitted to the general hospital—guidelines for the development of liaison mental health services for older people. 2005. www.rcpsych.ac.uk/pdf/whocareswins.pdf.

9 NHS Confederation. Acute awareness: improving hospital care for people with dementia. 2010. www.nhsconfed.org/ /media/Confederation/Files/Publications/Documents/Dementia report_Acute_awareness.pdf.

10 Alzheimer's Society. Counting the cost: caring for people with dementia on hospital wards. 2009. www.alzheimers.org.uk/countingthecost.

11 Alzheimer's Society. Dementia Action Alliance. www.alzheimers.org.uk/site/scripts/ documents_info.php?documentID=2432.

12 Royal College of Nursing. Improving quality of care for people with dementia in general hospitals. 2010. www.hospitaldr.co.uk/Dementia\%20care_EN_1.pdf. 
13 John's Campaign. John's Campaign: for the right to stay with people with dementia in hospital. http://johnscampaign.org.uk/\#/.

14 King's Fund. Environments of care for people with dementia. www.kingsfund.org.uk/ projects/enhancing-healing-environment/ehe-in-dementia-care.
15 Royal College of Psychiatrists. National audit of care of people with dementia in general hospitals: second round audit report and update 2012-13. www.rcpsych.ac.uk/pdf/NAD\% 20NATIONAL\%20REPORT\%202013\%20reports\%20page.pdf.

Published by the BMJ Publishing Group Limited. For permission to use (where not already granted under a licence) please go to http://group.bmj.com/group/rights-licensing/ permissions 